\begin{tabular}{|c|c|c|}
\hline & $\begin{array}{l}\text { European Association for the } \\
\text { Development of Renewable Energies, Environment } \\
\text { and Power Quality (EA4EPQ) }\end{array}$ & $\begin{array}{l}\text { International Conference on Renewable Energies and Power Quality } \\
\text { (ICREPQ'12) } \\
\text { Santiago de Compostela (Spain), 28th to 30th March, } 2012\end{array}$ \\
\hline
\end{tabular}

\title{
Obtaining and Characterization of Biodiesel Water Emulsion
}

\author{
J. Aponte ${ }^{1}$, L. Llano ${ }^{2}$, V. Prada ${ }^{3}$ and A. Martinez ${ }^{4}$ \\ ${ }^{1}$ Department of Mechatronic Engineering \\ U.M.N.G., Military Nueva Granada University \\ Bogotá - (Colombia)
}

Phone number:+0571 6500000 Ext.:1272, e-mail: jorge.aponte@unimilitar.edu.co

${ }^{2}$ Department of Civil Engineering

U.M.N.G., Military Nueva Granada University

Bogotá - (Colombia)

Phone number:+0571 6500000 Ext.:1272, e-mail: luis.llano@unimilitar.edu.co

\author{
${ }^{3}$ Department of Mechatronic Engineering \\ U.M.N.G., Military Nueva Granada University \\ Bogotá - (Colombia)
}

Phone number:+0571 6500000 Ext.:1272, e-mail: vladimir.prada@unimilitar.edu.co

\author{
${ }^{4}$ Department of Chemistry \\ U.M.N.G., Military Nueva Granada University \\ Bogotá - (Colombia)
}

Phone number:+0571 6500000 Ext.:1272, e-mail: volta@unimilitar.edu.co

\begin{abstract}
This paper describes the obtaining process results of a biodiesel-water emulsion, which seeks to obtain a non-fossil fuel whose characteristics comply with its possible use in diesel engines ensuring fewer toxic emissions into the environment, for it to be made tests with different proportions were realized, having previously chosen the correct emulsifier for this application.
\end{abstract}

\section{Key words}

Biodiesel, Biofuel, Density, Emulsion, Emulsifier.

\section{Introduction}

An emulsion is a mixture of two partially miscible liquids, one of which is dispersed in the other through globules. A liquid (dispersed phase) is dispersed in the other (the continuous phase or dispersing phase). Many emulsions are of oil / water, edible fats as one of the most common types of oils found in everyday life. Examples of emulsions include butter and margarine, milk and cream, espresso, mayonnaise, photo-sensitive side of photographic film, the magma and the cutting oil used in metallurgy. In the case of butter and margarine, fat surrounds droplets of water (in a emulsion of water in oil), in milk and cream, water surrounds droplets of fat (in a emulsion of oil in water).

Emulsions are part of a class more generic of two-phase systems of matter called colloids. Although the terms colloid and emulsion are sometimes used interchangeably, emulsion tends to imply that quantity of the dispersed as the continuous are liquids.

There are three types of emulsions, the emulsification of oil and water (oleoacuosas) that has oil as the dispersed phase in water, which is the continuous phase. Hidrooleosas emulsions in oil or water, the water is dispersed in the oil, which is the external phase. Emulsions are sometimes not clearly defined, as the internal and external phase, instead of being homogeneous, contain portions of the opposite phase, an emulsion of this kind is called dual emulsion. In particular the industrial sector pay attention to the use of emulsions of oleoacuosas type as a method to residue control, such as magma globules of liquid iron-nickel can be dispersed within a continuous phase of liquid silicate [7]. In this process in preparing the emulsions is called emulsification.

There are three types of unstable emulsions: flocculation, where the particles are mass, cremation, where the particles are concentrated at the surface (or bottom, depending on the relative density of the two phases) of the mixture while staying separated and coalescence where the particles melt and form a liquid layer. [2-5]. 

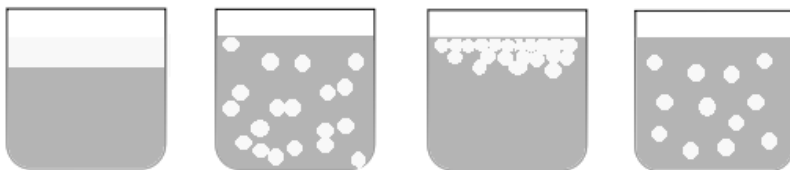

Fig 1. Unstable emulsion.

When an emulsion turns into water in oil emulsion or oil in water emulsion depends on the volume fraction of both phases and the type of emulsifier. Generally, the Bancroft rule applies: emulsifiers and emulsifying particles tend to promote dispersion of the phase in which they do not dissolve well, for example, proteins dissolve better in water than in oil so they tend to form oil in water emulsions (that is why they promote the dispersion of oil droplets throughout a continuous phase of water).

The basic color is white emulsions. If the emulsion is diluted, the Tyndall effect scatters the light and distorts the color to blue, if it is concentrated, the color is distorted towards yellow. This phenomenon is easily seen by comparing skim milk (free or low fat) cream (with high concentrations of milk fat). Microemulsions and nanoemulsions tend to be clear because of the small size of the dispersed phase.

\section{Process for obtaining}

After obtaining biodiesel from cooking oil is made by washing precipitated funnel until the wash water as clear as possible or obtains neutral $\mathrm{pH}$ after centrifugation was performed to remove waste glycerin. [1,6]. (Figures 2, 3 and 4).

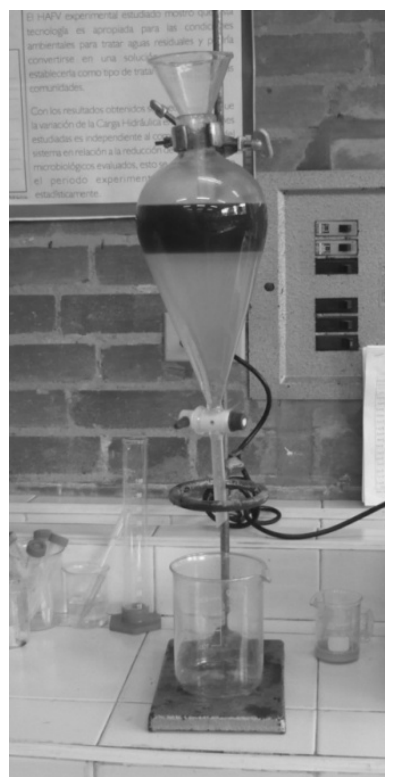

Fig. 2. Washing of biodiesel.

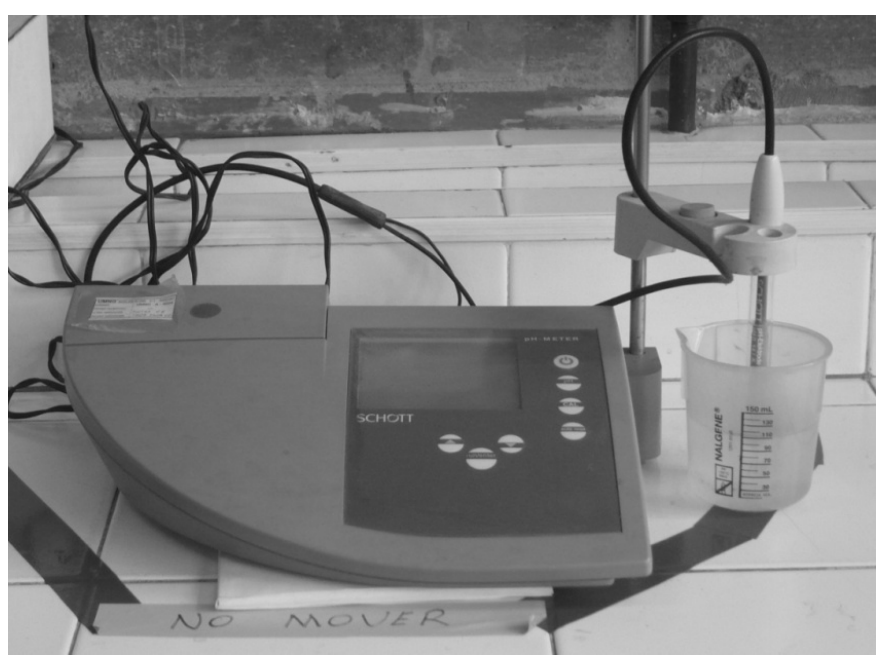

Fig. 3. Instrument for measuring $\mathrm{pH}$.

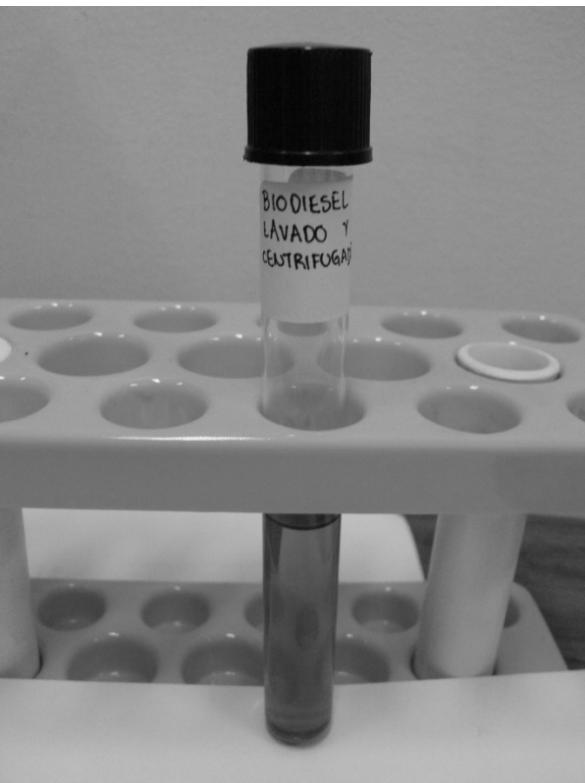

Fig. 4. Biodiesel washing and spinning.

With biodiesel processing (washing and spinning) proceeded to do tests with the ethoxylate nonyl phenol [3, 8] working as an emulsifier and water. They began by determining what type of emulsion could be obtained from biodiesel-water or water-biodiesel in the following proportions (Fig. 5):

\begin{tabular}{|lccc|}
\hline TEST & BIODIESEL & WATER & EMULSIFIER \\
\hline Test 1 & $25 \%$ & $75 \%$ & $1 \%$ \\
\hline Test 2 & $50 \%$ & $50 \%$ & $1 \%$ \\
\hline Test 3 & $75 \%$ & $25 \%$ & $1 \%$ \\
\hline
\end{tabular}




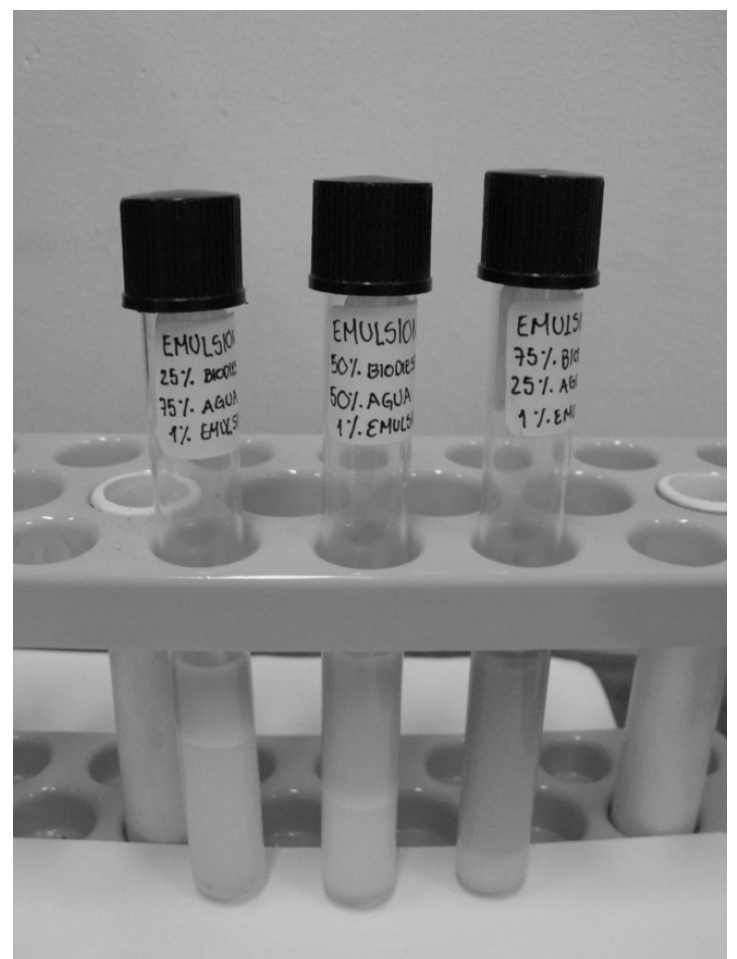

Fig. 5. Test Biodiesel - Emulsifier.

Best result was obtained in the test 3 , by determining the best water in biodiesel emulsion. According to this result was decided to conduct a test to determine the behavior of the emulsifier between biodiesel and diesel with the same proportion, obtaining the following results (Fig. 5):

\begin{tabular}{|lccc|}
\hline TEST & FUEL & WATER & EMULSIFIER \\
\hline Test 4 & $\begin{array}{c}75 \% \\
\text { BIODIESEL }\end{array}$ & $25 \%$ & $1 \%$ \\
\hline Test 5 & $75 \%$ DIESEL & $25 \%$ & $1 \%$ \\
\hline
\end{tabular}

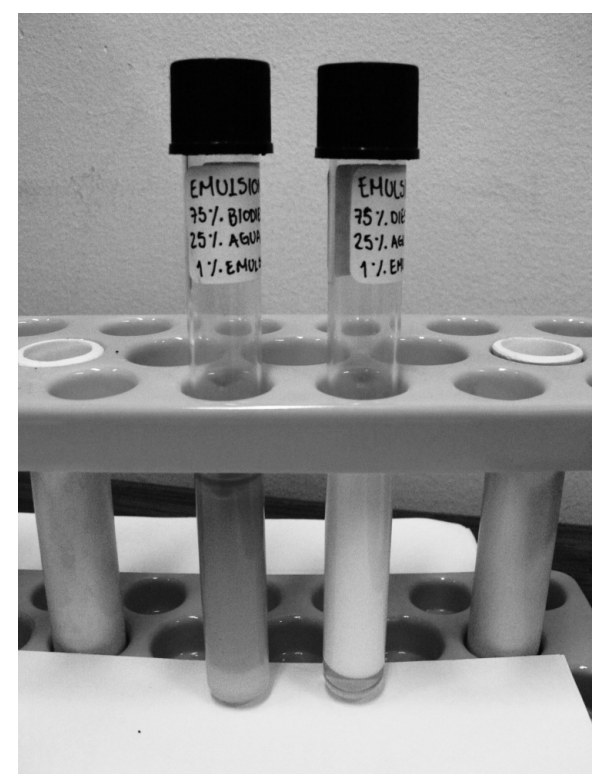

Fig. 6. Test water in biodiesel and water in diesel.

Tests 4 and 5 determined that the emulsifier works on both biodiesel and diesel in an appropriate manner, namely without producing clumps and a low viscosity. From the emulsion is water in biodiesel proceeded to determine a specific proportion in which a better emulsion is obtained by varying the ratio between the two elements as follows (Fig. 6):

\begin{tabular}{|cccc|}
\hline TEST & BIODIESEL & WATER & EMULSIFIER \\
\hline Test 6 & $80 \%$ & $20 \%$ & $1 \%$ \\
\hline Test 7 & $85 \%$ & $15 \%$ & $1 \%$ \\
\hline Test 8 & $90 \%$ & $10 \%$ & $1 \%$ \\
\hline Test 9 & $95 \%$ & $5 \%$ & $1 \%$ \\
\hline
\end{tabular}

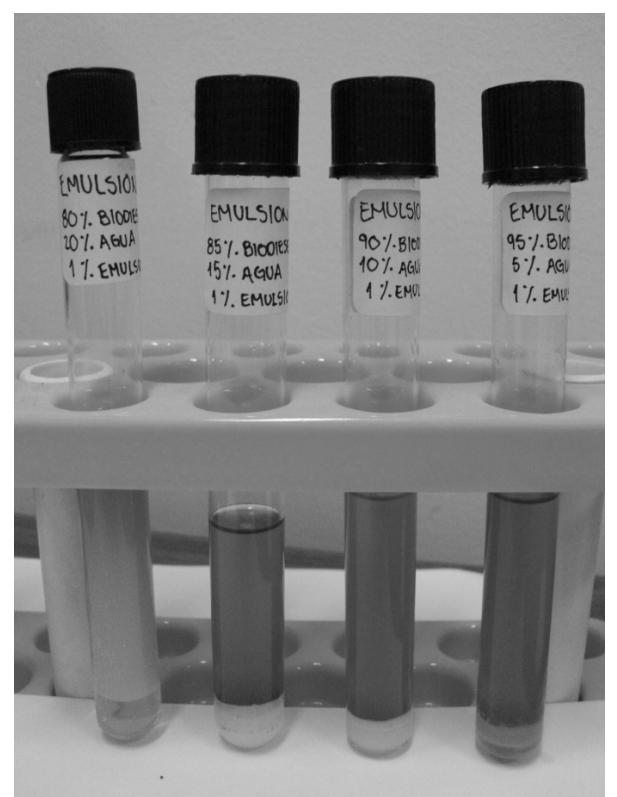

Fig. 7. Tests (Water - Biodiesel) in different proportions Emulsifier.

From these tests the best test emulsion was 6 . With this test it was determined that the reaction was not emulsified water, which is preceded by varying the ratio between water and biodiesel in a range between $80 \%$ and $85 \%$ biodiesel and the proportion of emulsifier.

\section{Results}

The fuel obtained was tested in a single cylinder diesel engine with a displacement of 300 cubic centimeters which produces 6 horsepower. There were no malfunctions or failures in engine systems, highlighted the ease of engine cold start and the significant reduction in soot in exhaust gases.

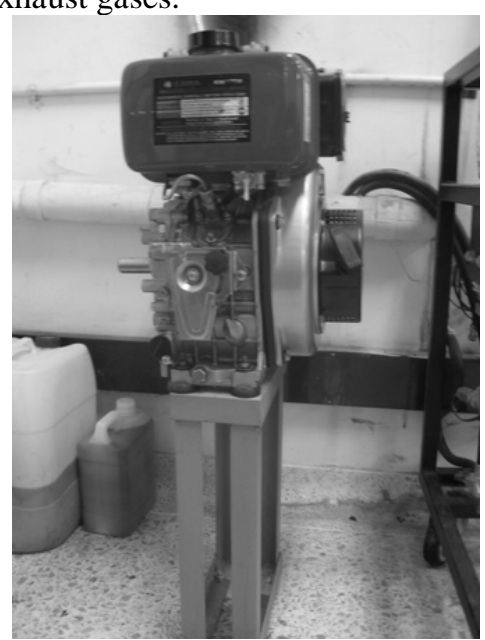

Fig. 8. Test motor diesel with biodiesel. 
Additionally, request the characterization in the Nacional University of two different substances Biodiesel and water, which yields the following information.

Tabla I. Results Biodiesel Characterization.

\begin{tabular}{|l|l|r|}
\hline PRUEBA TECNICA & NORMA ASTM & RESULTADO \\
\hline Densidad (kg/m3@15.56 $\left.{ }^{\circ} \mathrm{C}\right)$ & D-287 & 904.0 \\
\hline Grados API & D-287 & 25 \\
\hline Punto de inflamación $\left({ }^{\circ} \mathrm{C} @ 101.325 \mathrm{kPa}\right)$ & D-92 & 153 \\
\hline Punto de combustión $\left({ }^{\circ} \mathrm{C} @ 101.325 \mathrm{kPa}\right)$ & D-92 & 188 \\
\hline Viscosidad (cSt@40 $\left.40^{\circ} \mathrm{C}\right)$ & D-445 & 9.23 \\
\hline Curva de destilación & D-86 & Nota1 \\
\hline $\begin{array}{l}\text { Nota 1: Durante la medición de la curva de destilacion la muestra se expandio de torma violenta, generando transterencia de } \\
\text { muestra liquida al destilado. Al no poder medir el punto medio de ebullición no puede calcularse el indice de cetano. }\end{array}$
\end{tabular}

Tabla II. Results Biodiesel-water Characterization.

\begin{tabular}{|l|l|l|}
\hline PRUEBA TECNICA & NORMA ASTM & RESULTADO \\
\hline Densidad $\left(\mathrm{kg} / \mathrm{m} 3 @ 15.56^{\circ} \mathrm{C}\right)$ & D-287 & 895.0 \\
\hline Grados API & D-287 & 26 \\
\hline Punto de inflamación $\left({ }^{\circ} \mathrm{C} @ 101.325 \mathrm{kPa}\right)$ & $\mathrm{D}-92$ & Nota 1 \\
\hline Punto de combustión $\left({ }^{\circ} \mathrm{C} @ 101.325 \mathrm{kPa}\right)$ & $\mathrm{D}-92$ & Nota 1 \\
\hline Viscosidad $\left(\mathrm{CS}+440^{\circ} \mathrm{C}\right)$ & D-445 & 198.5 Nota 2 \\
\hline Curvade destilación & D-86 & Nota 3 \\
\hline
\end{tabular}

Nota 1: Durante la determinación del punto de inflamación se produjo ebullición y expulsión de la muestra de la copa, lo que impidió la determinación.

Nota 2: La reproducibilidad es superior a la máxima establecida por la norma. La muestra se adhiere a las paredes del capilar lo que modifica la homogeneidad, hecho que incide sobre la reproducibilidad. Nota 3: Durante la medición de la curva de destilación la muestra se expandió de forma violenta, generando transferencia de muestra liquida al destilado. Al no poder medir el punto medio de ebullición no puede calcularse el índice de cetano.

\section{Conclusion}

The test 6 presented high homogeneity and stability after the time is no visual separation between the biodiesel and water.

The motor behavior of the emulsion was within the ranges established a consistent behavior and emissions of gases decreased considerably.

The ethoxylated nonyl phenol emulsifier gave satisfactory results both in the homogeneous mixture as engine performance and emissions. It is therefore advisable to use in internal combustion engines; hold the precaution of periodic maintenance, evaluating the rate of corrosion due to the presence of water in the emulsion.

Additional stability can be achieved by the introduction of surfactants or stabilizers.

\section{References}

[1]. Chen Hao. Preparation and Performances of Biodieselethanol water Micro-emulsion Fuels. Automobile faculty. Chang' an university. Xi' an city, China

[2]. Emulsions. In: http://www.textoscientificos.com/emulsiones/introduccion. Consulted: 10 de junio de 2011.

[3]. Propiedades y caracteristicas de combustibles diesel y biodiesel. Wearcheck Ibérica. 9 de Julio de 2004.

[4]. Revista Asuntos Diesel, abril 2009, pag 6-141

[5]. In: http://dictionary.reference.com/browse/Emulsion. Consulted: 10 de junio de 2011.

[6]. Allen M. and Prateepchaikul G., The modelling of the biodiesel reaction. Consulted el 3 - march de 2008.
[7]. In: http://journeytoforever.org/biofuel_library/modelling.pdf

[8]. ECO2SITE, 2004. Biodiesel en el Mundo. In: http://www.eco2site.com/informes/biodiesel-m.asp. Consulted: 23 de February de 2007.

[9]. Sasol. Reaching new frontiers. Alcoholes etoxilados. 23 march 2006.

[10].U.S. Environmental Protection Agency, 2002. A Comprehensive Analysis of Biodiesel Impacts on Exhaust Emissions. Consulted el 6 - march 2008. In: http://www.epa.gov/otaq/models/analysis/biodsl/p02001.p df 